\title{
A Case of the Girl Who Reframed the Death of Her Father
}

\author{
1) Doshisha Junior and Senior High School \\ KEY WORDS: wrist-cutting, grief work, reframing
}

Shuhei Iwamoto ${ }^{1)}$

The client was a ninth grade's girl who complained that she could not stop wrist-cutting. In her treatment period, her father died. She could find the meaning of his death and she finally overcame various difficulties. In this report, I present the assessment, the intervention and the consequence of this case.

\section{Interview process}

\section{1) Character of the client}

When the client was in the sixth grade, her parents got divorced. Her mother often left her and her younger brother at her grandmother's house because she started to work at a nightclub. When she was in the eighth grade, she cut her wrist for the first time, thinking of her one-time boyfriend. A month later, her mother knew that the client sometimes cut her wrist, and after that the mother frequently said to her daughter "I can't concentrate on my work because you are a worry to me! Get out of this house!" After a few days, when the client

CoRRESPONDENCE TO: Iwamoto, Doshisha Junior and Senior High School, 89, Iwakura Osagichou, Sakyoku, Kyoto-city 606-8558, Japan. e-mail: eto1503@yahoo.co.jp came to the nurse's office, she told the nurse that she cut her wrist habitually. The teacher let her see to a psychiatrist and she started to receive the treatment. Her overdosing made her grandmother to control her medicine. In January when she was in the ninth grade, she knew that her father remained only a short time to live because he got cancer. After hearing the fact, she cut her wrist in the restroom at the station.

When she was in junior high school, sessions were held once a week. After entering high school, sessions were held once a month, and a total of 12 sessions were carried out.

\section{Sessions before her father's death}

(\#1:January 22, X \#4:February 12, X)

\section{Describe her solution}

In the first session, the client said, "If Mom and I calm down our nerves, I don't need to take medicine and we can be a peaceful family. That's the solution." She also told that she cut her wrist when she did not feel needed by the people around her.

\section{Interventions from counselor}

The counselor suggested the client 1) not to stop cutting her wrist and 2) to search for small 
happiness (positive change) in her daily life.

\section{Positive changes}

The client reported, "I can be relaxed when I'm with my favorite teacher." (\#2) In addition, she reported, "When I go in my mom's bed, she hug me tightly." and, "I can calm down talking with the nurse teacher or the counselor." (\#3) In her fourth session, she reported that her friends supported her and teachers understood her difficulties. She told that thinking her parted boyfriend had no longer caused her to cry and wrist-cut.

\section{About her father}

The client reported that her father was in critical condition. She thought he was a hero for her. She wanted to do something for him but she had no ideas. She grieved, "Why my dad will die? I wish I had cancer instead of him."

\section{Interventions from counselor to "A"}

The counselor suggested the client 1) to think about how to make her father a "hero" and 2) bake cookies to respond to her father's request.

\section{Sessions after her father's death}

(\#6:February 26, X \#12:August 27, X)

\section{About her father}

On February 22 of X, the client's father died of cancer. She was worried about whether it was a burden to her father that she visited him in the hospital. She regretted and said, "I should die instead of him because I often cut my wrist." In this stage, she could not accept her father's death, while she felt his love. She said, "My dad called me 'princess' in E-mail."(\#6) She started to think her wrist-cutting in relation to her father's death. She said, "I wished that my dad live long. Therefore, I should not cut my wrist anymore. It's my dad's happiness to keep myself in good health and be happy." She started to accept his father's death. (\#8) Her cousin was born on the day her father was diagnosed as that he could not live long. She believed that there was a precious destiny between her father and her cousin. She came to take care of him eagerly and talk about the hope to live.

\section{Interventions from counselor}

The counselor suggested the client 1) to take much time to accept her father's death and 2) to search for whatever she saw positive (positive changes).

\section{Positive changes}

Her grandmother suggested the client to talk about the relation with her mother. As a result, the relation with her mother became stable. After that, she told that she was getting well and enjoying her part time job. At the 12th session, she told that she had conflicts with her mother, but she could handle the problem by talking with her grandmother.

\section{Decision of what to do after graduation}

The client started to talk about her career path. She talked with her homeroom teacher and school nurse and decided to change her school to be a beautician.

\section{After changed school}

In December, $X$, the client moved to her new school. In May, X+1, she told the counselor 
that she stopped wrist-cutting and passed the credits. She came to be on good terms with her mother.

\section{Discussions}

\section{1) Vicious circle}

The client cut her wrist when her mother blamed her. The mother also blamed her when she saw her daughter wrist-cutting. At first session, the counselor asked her to search for the positive change in her daily life and not to stop wrist-cutting. Then she found that she was supported by the people around her. That made her feel needed by them. I can maintain that the sense of feel needed reduced her wrist-cutting.

\section{2) Her father's death and her change}

The client tried to feel her existence with wrist-cutting because she felt nobody needed her. The relationship with her mother, one-time boyfriend, and father made her depressed. As the treatment was progressing, she started to search for her positive change and found that her teachers, friends and family have supported her. She had the chance to realize her resources and a fact that people helped each other to live. Wrist-cutting had been necessary for her to calm down herself before, but after her father died, she thought wrist-cutting made her father sad and must not be done. She was willing to do something for her father. Therefore, she stopped her wrist-cutting. She had a desire to make her father happy. To make him happy, she thought she had to become happy. "For her father" became a good message for her. As the other way to be happy, she changed her career path and school to become a beautician.

In this case, her father gave her the reason for living. Yokohori (2000) stated that grief is not cured by someone, but the person who has lost someone or something tries to reorganize his/her experiences, finds the meaning of the loss and gets the power from it, with a support from the people around him/her.

As a conclusion, the main point of this case is that she restructured the meaning of her father's death, overcame her problem and found the new career path.

\section{References}

Yokobori, M. (2000). Possibility and Needs of the Grief Work Practice in the Japanese welfare Institution. Journal of Aoyama Gakuin Woman's Junior College, 54, 151-178. [in Japanese]（横堀 昌子 (2000). 福祉現場に おけるグリーフワーク〜実践の可能性と必 要性。青山学院女子短期大学紀要，54, 151-178.) 